\title{
Child maltreatment, abuse and neglect in a Nigerian adolescent boy, the common but unheard menace: A case report form Southwest, Nigeria
}

\author{
Chinyere C. Uzodimma*, Morufat M. Ogundeyi, Florence I. Dedeke, Olasunkanmi Owolabi \\ Department of Paediatrics, Federal Medical Centre, Abeokuta, Nigeria \\ Email: ${ }^{*}$ cuzodimma@yahoo.com
}

Received 23 October 2013; revised 20 November 2013; accepted 27 November 2013

Copyright (c) 2013 Chinyere C. Uzodimma et al. This is an open access article distributed under the Creative Commons Attribution License, which permits unrestricted use, distribution, and reproduction in any medium, provided the original work is properly cited.

\begin{abstract}
Child abuse is a global problem. It includes all forms of physical and emotional ill-treatment, sexual abuse, neglect, and exploitation that result in actual or potential harm to the child's health, development or dignity. Child abuse and neglect are common in Nigeria, yet poorly reported. We herein report a case of child abuse and neglect in a 14-year-old boy, complicated by severe malnutrition, human immunodeficiency virus infection and gross under achievement of educational goal. The social and economic factors that play major roles are highlighted with the aim of sensitizing health care professionals, child advocacy groups, policy makers and other stakeholders on the impact of child abuse. We also hope that this would remind all concerned organisations and individuals of child protection which is integrated in the child right act 2003 adopted by Nigeria.
\end{abstract}

Keywords: Child Abuse; Child Neglect; Child Protection; Nigeria

\section{INTRODUCTION}

Child maltreatment, sometimes referred to as child abuse and neglect, includes all forms of physical and emotional ill-treatment, sexual abuse, neglect, and exploitation that result in actual or potential harm to the child's health, development or dignity. Within this broad definition, five subtypes can be distinguished-physical abuse; sexual abuse; neglect and negligent treatment; emotional abuse; and exploitation [1]. Child physical abuse is very common in Nigeria and yet poorly reported [2]. The consequences of physical child abuse are grave. Most child physical abuse is perpetrated in guise as corporal pun-

"Corresponding author. ishment. In some opinions, corporal punishment is a long spectrum; at one end it may be corrective especially if the child can connect the punishment to a demeanour. However, when corporal punishment results in actual or potential harm, it becomes clearly abusive. The use of corporal punishment by adults having authority over children is likely to train children to use physical violence to control behaviour rather than rational persuasion [3]. There is a need to draw attention of healthcare professionals, policy makers and child advocacy groups to this menace-turned norm. We hope that this report will remind all concerned groups and individuals of the child right act 2003 in which Nigeria engaged.

\section{CASE SUMMARY}

We present OM, a 14-year-old adolescent who was brought into the Emergency room by a social worker requesting for medical examination. A neighbour had alerted a local non-governmental organization, Terres Des Hommes, about their observation of the child's experiences at home.

OM gave a history of weight loss of three months duration, two months history of cough and two months history of low grade continuous fever.

There is no history of previous blood transfusion and no history of similar symptoms in the family. OM's hair cut is usually done with unsterilized barbing instruments in nearby barbing shop. There is no history of engagement in any form of sexual relationship.

$\mathrm{OM}$ also reported multiple episodes of physical abuse by his father allegedly due to his (OM) established night snoring. He was often deprived of food and prevented from going to school or interacting with the neighbours. Attention was called by a sympathetic neighbour who alerted Terre Des Homme (a non-governmental organization). 
OM's parents have been separated for ten years. (OM was four years old at the time of parental separation). He is the only child of the marriage. After the separation of his parents, OM lived with his paternal grandmother from the age of four until age often years old when the said grandmother died. Subsequently, he was left with a maternal aunt who continued his foster care until a year ago when he was returned to his father at the age of thirteen years. The aunt hitherto had complained about economic challenges that made it difficult for her to continue to take care of $\mathrm{OM}$ in addition to her other six children.

OM's father is currently in another marital relationship that has produced seven other children. His mother is also re-married with three other children. OM's father is 40 years old, an unskilled worker while the mother is currently 38 years old and an unemployed house wife. Both parents have no formal education.

$\mathrm{OM}$ is currently in primary school grade five. (14year-old children are mostly in grade 10). OM's education is reported to have been interrupted due to frequent absenteeism from school (financial, illnesses, deliberate denial by father and recurrent re-location).

Physical examination revealed an acute on chronically ill-looking, small for age adolescent. He was unkempt with fluffy sparse scalp hair, profuse tineacapitis, mildly pale, not cyanosed, febrile (temperature-37. $7^{\circ} \mathrm{C}$ ) and in respiratory distress, He had profuse oral thrush, right submandibular non-tender lymph node enlargement and multiple axillary lymphadenopathy. There were multiple linear hyper pigmented loop marks over his back and the upper limbs (Figure 1). OM weighed $20 \mathrm{~kg}$ (below the fifth centile [4]) and was $136 \mathrm{~cm}$ tall (below the fifth centile [4]). Other significant findings were tachycardia (rate-150 beats/min) and tender swelling of the dorsum of the right hand with patterned marking at his back.

Investigations showed anaemia (packed cell volume was 28\%), left lobar consolidation and positive ELISA and western blot test for human immunodeficiency virus 1 (HIV 1). His CD4 cell count was 104 cells/ $\mu$ l (this sig-

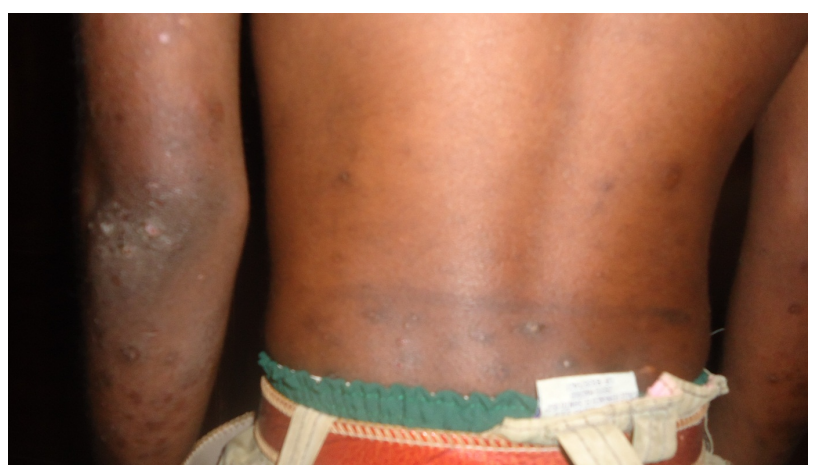

Figure 1. Multiple linear hyper pigmented loop marks over the back and the upper limbs. nifies severe HIV associated immunodeficiency [5]). Adenoids were enlarged with airway obstruction. Both parents were HIV negative.

He was commenced on anti-retroviral medicationsLamivudine, Zidovudine, Nevirapine and social counselling of family was done. Due to lack of established formal social support institutions, OM had to be transferred back to the maternal aunt after evaluation by the social support Department of the Hospital. The said aunt received welfare allowance from Terres de Hommes in view of this.

\section{DISCUSSION}

Child abuse is a global problem. The global incidence of physical abuse is about $226 / 1000$ by a recent metaanalysis [6]. In the United States of America, a survey of families showed that 140 out of 1000 children (14\%) were physically abused in varying techniques in one year [7]. There is dearth of data on prevalence and incidence of child physical abuse in Nigeria. However, child sexual abuse, child labour and child neglect are more often reported than physical abuse in form of corporal punishment [8-12]. Lack of effective structures for reporting of physical abuse of children together with socio-cultural belief may account for this dearth of published data. Child abuse is not limited to homes; there is also abuse in the school and other institutions $[11,13,14]$. Surveys indicate that corporal punishment remains legal in at least sixty countries for juvenile offenders and at least sixtyfive countries in schools and other institutions [13]. The cause of physical child abuse is multi-factorial. In this report, we examine the complex interaction of factors that contributed to the physical abuse, maltreatment and neglect of the adolescent boy.

The ecological model is generally regarded as the ideal conceptual framework from which to approach the complex interactions among the care giver, child, family, social situation and cultural values leading to physical abuse of the child [15]. This model sees the child functioning within the family (microsystem), the family functioning within the community (exosystem), the various communities linked together by a set of socio-cultural values that influence them (macrosystem) and all of these systems operating over time (chronosystem) [15]. Each of these systems is inter-related and therefore affects one another.

In the case of OM, the microsystem is disordered greatly. A multiplicity of factors aggravated the impact. Parental divorce, large family size in spite of poor socioeconomic achievement of the parents, lack of education and health illiteracy could be seen as major confounders contributing in various ways to microsystem disequilibrium. Family sizes of at least six children were reported for OM's father and the maternal aunt. Countries need to 
invent ingenious ways to tackle oversizing of families as this has implication for child right and protection. One of the ways could be providing stipends for unemployed mothers as well as effective child protection systems for abused children. Very importantly, the place of health illiteracy needs to be highlighted; the perpetual punishment of the child whose snoring is due to adenotonsillar hypertrophy is inhuman and highly condemnable. One also understands that the father did this out of profound health illiteracy and inclination to corporal punishment. Public education in line with improving health literacy in the community is one of the key solutions. Medical neglect is evident from the protracted duration of the illness before presentation, the severe malnutrition and ultimately the practices that endangered the child to HIV infection. There is need for HIV prevention campaign to positively influence the local barbers by teaching them and advocating for a cost effective means of sterilizing barbing materials. Provision of accessible and affordable health care and health insurance system will undoubtedly encourage parents to seek medical attention in the hospitals rather than resort to physical threats for misinterpreted ill-health related symptoms.

The exosystem in this circumstance was rescuing with respect to the role of foster care given by the extended family for about nine years as well as the rescuing role of the neighbour. The government should prioritise development of effective social support/child protection systems for abused and displaced children. Such systems should effectively network with the community and the health care system. Furthermore, the social support and child protection systems should be accessible with effective, practicable reporting system for them to be meaningful.

We also need to examine the child right act 2003 which was adopted by the Nigerian Government. The Child Rights Act 2003 (CRA) incorporates all the rights and responsibilities of children; consolidates all laws relating to children into a single law; and specifies the duties and obligations of government, parents and other authorities, organizations and bodies [16]. Within the CRA, "no Nigerian child shall be subjected to physical, mental or emotional injury, abuse or neglect, maltreatment, torture, inhuman or degrading punishment, attacks on their honour or reputation" [16]. Having enacted the law in 24 out of 36 states of the federation [16], there is call for the remaining states of the federation to adopt the law as well for the effective implementation and administration of the contents as stipulated by law.

The American Psychological Association resolves thus, "corporal punishment intended to influence undesirable response may create in the child the impression that he or she is an undesirable person and an impression that lowers self-esteem and may have chronic consequences” [3].
Research has also shown that adverse childhood experiences reflecting violence in the family have implications for mental health consequences in adult life [17].

\section{CONCLUSION}

Child abuse, maltreatment and neglect are social menace whose negative impact on child development cannot be over-emphasized. The index case report exposes the far reaching impact of family separation, poor parental education, low parental socio-economic status and very sadly lack of social support and child protection structure for fostering of abused and neglected children in Nigeria. There is a need to set up more functional social support and child protection system as well as effective child fostering and adoption systems in Nigeria. Parents, individuals or institutions that violate the CRA should be prosecuted. Paediatricians and other child advocates are reminded of their crucial role in child protection. There is an intense need for guidelines on what to do if one finds an abused child.

\section{REFERENCES}

[1] World Health Organisation (2013) Child maltreatment. http://www.who.int/topics/child_abuse/en

[2] Okeahialam, T.C. (1984) Child abuse in Nigeria. Child Abuse \& Neglect, 8, 69-73.

http://dx.doi.org/10.1016/0145-2134(84)90051-6

[3] American Psychological Association Policy Statement (2013) Corporal punishment.

http://www.apa.org/about/policy/corporal-punishment.aspx

[4] (2013) 2 - 20 yrs: Boys stature-for-age and weight-forage percentiles.

http://www.cdc.gov/growthcharts

[5] (2013) WHO case definitions of HIV for surveillance and revised clinical staging and immunological classification of HIV-related disease in adults and children. http://www.who.int/hiv/pub/guidelines/hivstaging/en/

[6] Stoltenborgh, M., Bakermans-Kranenburg, M.J., Yan Ijzendoorn, M.H. and Alink, L.R. (2013) Cultural geographical differences in the occurrence of physical child abuse? A meta-analysis of global prevalence. International Journal of Psychology, 48, 81-94.

http://dx.doi.org/10.1080/00207594.2012.697165

[7] Johnson, C.F. (2000) Abuse and neglect of children. In: Behrman, R.E., Kleigman, R.M. and Jenson, H.B., Eds., Nelson Textbook of Pediatrics, 16th Edition, WB Saunders Company, Philadelphia, 110-114.

[8] Audu, B., Geidam, A. and Jarma, H. (2009) Child labour and sexual assault among girls in Maiduguri, Nigeria. International Journal of Gynacology and Obstetrics, 104, 64-67. http://dx.doi.org/10.1016/j.ijgo.2008.09.007

[9] Obisesan, K.A., Adeyemo, A.A. and Onifade, R.A. (1999) Childhood sexuality and child sexual abuse in South West Nigeria. Journal of Obstetrics \& Gynecology, 19, 
624-626. http://dx.doi.org/10.1080/01443619963897

[10] Omorodion, F.J. (1994) Child sexual abuse in Benin City, Edo state Nigeria: A sociological analysis. Issues Comprehensive Pediatric Nursing, 17, 29-36. http://dx.doi.org/10.3109/01460869409078286

[11] Wilson, E.B. and Afamefuna, G.C. (1986) Child abuse in institutions: The case of day care centres in Nigeria. Child Abuse \& Neglect, 10, 93-98. http://dx.doi.org/10.1016/0145-2134(86)90037-2

[12] Wilson-Oyelaran, E.B. (1989) The ecological model and study of child abuse in Nigeria. Child Abuse \& Neglect, 13, 379-387. http://dx.doi.org/10.1016/0145-2134(89)90078-1

[13] (2013) World report on violence and health. http://www.who.int/violence_injury_prevention/violence/ global_campaign/en/chap3.pdf
[14] Chianu, E. (2000) Two deaths, one blind eye, one imprisonment: Child abuse in the guise of corporal punishment in Nigeria schools. Child Abuse \& Neglect, 24, 10051009. http://dx.doi.org/10.1016/S0145-2134(00)00154-X

[15] Giardino, A.P., Giardino, E.R. and Moles, R.L. (2013) Physical child abuse.

http://www.emedicine.medscape.com/article/915664-over veiw

[16] UNICEF Nigeria-Fact sheet. Child rights legislation in Nigeria (2013)

http://www.unicef.org/nigeria/Child_rights_legislation_in _Nigeria.pdf

[17] Oladeji, B.D., Makanjuola, V.A. and Gureje, O. (2010) Family related adverse childhood experiences as risk factors for psychiatric disorders in Nigeria. British Journal of Psychiatry, 196, 186-189. 